\title{
Jurist-Diction
}

Volume 3 No. 6, November 2020

\section{Pengaturan Pemungutan Pajak Penghasilan Bagi Kegiatan Jasa Titip Barang Impor}

\author{
Novita Wahyu Indriyanti
}

novita.wahyu.indriyanti-2016@fh.unair.ac.id Universitas Airlangga

\begin{abstract}
How to cite:
Novita Wahyu Indriyanti, 'Pengaturan Pemungutan Pajak Penghasilan Bagi Kegiatan Jasa Titip Barang Impor' (2020) Vol. 3 No. 6 November JuristDiction.

Histori artikel:

Submit 1 Agustus 2020;

Diterima 21 September 2020;

Diterbitkan 1 November 2020.

DOI:

10.20473/jd.v3i6.22973
\end{abstract}

\begin{abstract}
Abstrak
Kegiatan Jasa Titip barang impor merupakan sebuah layanan jasa dimana individu yang berlaku sebagai penyedia jasa bepergian ke suatu negara tertentu untuk membelikan barang-barang yang telah dipercayakan oleh pelanggan untuk dibelikan oleh penyedia jasa dan barang-barang tersebut akan dibawa kembali ke Indonesia untuk kemudian diserahkan kepada pelanggan tersebut dengan melakukan sejumlah pembayaran (fee) untuk penyedia jasa. Kegiatan meningkatkan minat daya beli masyarakat untuk jasa titip menjadi konsumtif terhadap barang impor. Kegiatan jasa titip barang impor merupakan kegiatan usaha baru yang belum memiliki peraturan perundangan - undangan yang mengatur sehingga banyak pelaku kegiatan jasa titip yang menggunakan berbagai cara untuk lolos dari beban perpajakan, salah satunya pajak penghasilan. Dalam pengenaan pajak penghasilan terdapat dua pengenaan yang berbeda terhadap pelaku kegiatan jasa titip yaitu pelaku kegiatan jasa titip yang memiliki NPWP dan non NPWP. Terkait belum adanya peraturan perundang -undangan yang mengatur, diperlukan adanya penghalusan hukum atas peraturan perundang-undangan yang sudah ada sebagai suatu upaya penegakan hukum bagi tindakan pelaku kegiatan jasa titip yang melanggar norma hukum.

Kata Kunci: Pelaku Kegiatan Jasa Titip (handcarry); Pajak Penghasilan; Penegakan hukum.
\end{abstract}

\section{Pendahuluan}

Jasa Titip barang impor merupakan sebuah layanan jasa atas pembelian barang impor melalui individu yang menjalankan layanan jasa titip dengan melakukan perjalanan ke luar negeri untuk membeli produk impor yang diinginkan oleh konsumen layanan jasa titip lalu kemudian barang tersebut akan dibawa kembali ke Indonesia untuk diserahkan kepada konsumen dengan penerimaan upah bagi penyedia layanan jasa titip. Pelaku jasa titip dalam menyelenggarakan jasa titip barang impor memiliki beberapa kewajiban yang melekat pada dirinya, salah satunya kewajiban perpajakan. 
Pengenaan pajak dapat dikenakan terhadap barang impor sebagai objek dari kegiatan jasa titip impor yang memiliki nilai jual dan kemanfaatan bagi penjual dan pembeli. Sehingga atas pendapatan yang diperoleh akan dikenakan beban pajak penghasilan. Kegiatan jasa titip barang impor ini dilakukan oleh penyedia jasa titip barang impor dengan mengumpulkan mengumpulkan terlebih dahulu pelanggan yang akan menggunakan jasanya untuk menutupi biaya perjalanan atau transportasi ke suatu negara yang dituju. Fee layanan jasa titip yang cukup menutupi biaya transportasi tentunya begitu menguntungkan penyedia jasa jasa titip yang dapat menikmati liburan singkat secara gratis tanpa mengeluarkan uang pribadi selagi bekerja untuk membelikan barang - barang yang telah dipesan oleh pelanggan. Salah satu keuntungan itulah yang membuat penyedia jasa titip barang impor semakin marak di Indonesia. Pekerjaan yang relatif mudah dimana siapapun bisa melakukannya tanpa harus memiliki background pendidikan yang tinggi serta kesempatan berjelajah ke negeri orang yang besar menjadi alasan yang cukup kuat untuk perorangan menawarkan jasanya untuk perjalanan jasa titip barang impor. Pembeli yang merupakan pengguna dari layanan jasa titip barang impor cenderung lebih menyukai penggunaan layanan jasa titip karena pembeli akan menerima barang impor yang dipesan secara langsung dan bersih dari segala besaran beban perpajakan yang melekat pada barang impor apabila pembeli melakukan impor barang secara mandiri serta banyaknya resiko yang kerusakan barang ketika melalui impor langsung.

Hal tersebut berbeda ketika melakukan pembelian barang impor melalui jasa titip, resiko kerusakan barang akan sangat berkurang mengingat barang impor yang milik pembeli berada langsung dalam pengawasan jasa titip baik dari proses pemilihan barang hingga membawa barang tersebut ke Indonesia dan pembeli juga dapat setiap waktu menanyakan kepada jasa titip mengenai barang miliknya. Selain itu pembeli juga terbebas dari beban perpajakan yang melekat pada barang impor, bebas pajak yang dimaksudkan ialah pembeli tidak perlu secara mandiri mengurus pajak barang impor miliknya ketika melakukan pembelian barang impor melalui jasa titip karena seluruh pembebanan pajak akan menjadi tanggung jawab jasa titip 
untuk dibayarkan atas barang bawaan dari luar negeri sehingga pembeli hanya perlu membayar harga barang dan upah jasa titip dengan biaya pajak akan terbagi rata dengan pengguna jasa titip yang lain yang ketika itu bersama-sama mengikuti jasa titip barang impor kepada pelaku kegiatan jasa titip barang impor.

Mudahnya melakukan jasa titip barang impor dan meningkatnya minat masyarakat menggunakan jasa titip barang impor tentu berpengaruh dengan besaran bea masuk dan pajak barang impor yang diterima oleh Direktorat Jenderal Bea dan Cukai sebagai lembaga dibawah Direktorat Jenderal Pajak yang mengawasi dan berwenang atas pemungutan iuran pajak dari kegiatan ekspor impor barang sesuai dengan ketentuan perundang-undangan yang berlaku. Prosedur jasa titiip yang membawa barang impor titipan melalui bagasi pesawat maupun bagasi kabin pesawat dinilai memiliki celah besar untuk melakukan penghindaran pajak. Hal ini tentunya akan berpegaruh terhadap pendapatan negara dari sektor pajak barang impor. Minat yang tinggi akan menciptakan kegemaran baru bagi masyarakat untuk memilih berbelanja melalui layanan jasa titip daripada melalui impor langsung dimana hal ini secara tidak langsung dapat merubah pola pikir masyarakat yang akan cenderung memilih layanan jasa titip sebagai sarana berbelanja produk luar negeri yang tidak masuk pasar Indonesia dan mulai meninggalkan pembelian barang melalui proses impor langsung seperti pada umumnya.

Direktorat Jenderal Bea dan Cukai dengan Direktorat Jenderal Pajak yang mengetahui adanya layanan jasa titip yang semakin besar dan berpengaruh terhadap keuangan negara menetapkan pengenaan pajak terhadap barang impor yang masuk ke Indonesia melalui jasa titip dengan pengenaan pajak yang setara dengan pajak barang bawaan penumpang pesawat terbang dimana pelaku kegiatan jasa titip akan dibebankan pajak yang harus ditanggung sebagaimana diatur dalam Pajak Penghasilan Pasal 22. Besaran yang dikenakan terhadap barang impor terhadap pelaku kegiatan jasa titip adalah sebagai berikut:

- Pajak Penghasilan (PPh) sebesar 15\% untuk Wajib Pajak tanpa NPWP

- Pajak Penghasilan (PPh) sebesar 7.5\% untuk Wajib Pajak dengan NPWP

Pajak Penghasilan adalah pajak yang dikenakan terhadap subjek pajak atas penghasilan 
yang diterima atau diperoleh subjek pajak dari suatu tahun pajak ${ }^{1}$ Pajak penghasilan terhadap barang impor dikenakan terhadap pelaku kegiatan jasa titip dikarenakan kegiatan jasa titip yang dilakukan memenuhi syarat-syarat seseorang untuk dibebankan Pajak Penghasilan (PPh). Pajak Penghasilan dibebankan kepada pelaku kegiatan jasa titip karena kegiatan jasa titip adalah kegiatan yang menguntungkan baik bagi pelaku kegiatan jasa titip maupun pembeli barang impor sehingga diperlukan pengenaan pajak penghasilan dalam kegiatan jasa titip barang impor.

\section{Dasar Pengenaan Pajak Penghasilan Bagi Kegiatan Jasa Titip Barang Impor}

\section{A. Subjek Kegiatan Jasa Titip Barang Impor}

Kegiatan jasa titip barang impor dapat dilakukan oleh seluruh individu yang berminat untuk melakukan kegiatan jasa titip. Subjek kegiatan jasa titip adalah setiap individu yang memiliki tanggung jawab atas beban pajak penghasilan yang melekat pada kegiatan jasa titip impor barang. subjek kegiatan jasa titip adalah subjek pajak penghasilan yang merupakan segala sesuatu yang memiliki potensi untuk memperoleh penghasilan sesuai dengan peraturan perundang-undangan yang berlaku. Subjek kegiatan jasa titip tersebut ialah orang pribadi menurut pasal 2 ayat (2) Undang-Undang Nomor 36 Tahun 2008 yaitu orang pribadi yang bertempat tinggal di Indonesia atau Warga Negara Asing yang bertempat tinggal di Indonesia lebih dari 183 (seratus delapan puluh tiga) hari dalam jangka waktu dua belas bulan². Namun keberadaan pelaku kegiatan jasa titip WNA masih sangat jarang ditemukan karena keterbatasan akses bahasa dan kepercayaan pembeli yang tentunya lebih memilih orang pribumi. Subjek kegiatan jasa titip terbagi lagi atas dua subjek yaitu pelaku usaha dan non pelaku usaha. ${ }^{3}$ Pelaku usaha dalam kegiatan handcarry ditandai

1 Siti Resmi, Perpajakan teori \& kasus (Salemba Empat 2017).[55].

2 Undang -Undang Nomor 36 Tahun 2008 Tentang Pajak Penghasilan (Lembaran Negara Republik Indonesia Tahun 2008 Nomor 133, Tambahan Lembaran Negara Republik Indonesia Nomor 4893).

3 Erlin Cahyani Putrim, "Tax Planning Bagi Pelaku Usaha Jasa Titip ditengah Guncangan Kasus Penghindaran Pajak" (Pajakku, 2019) <https:/www.pajakku.com/read/5d9ff770b01c4b456747b70e/Tax-Planning-Bagi-Pelaku-Usaha-Jasa-Titip-di-Tengah-Guncangan-Kasus-Penghindaran-Pajak >, dikunjungi pada 09 Agustus 2020. 
dengan kepemilikan NPWP dimana beban pajak penghasilan yang dibebankan menjadi lebih ringan, yaitu adalah setiap orang yang berkedudukan atau melakukan kegiatan didalam wilayah hukum negara Republik Indonesia secara bersama sama ataupun mandiri melakukan kegiatan handcarry barang impor sebagai salah satu pekerjaan dan tujuan utama dari perjalanan ke luar negeri. Sedangkan non pelaku usaha dalam kegiatan handcarry impor ditandai dengan bukan merupakan pemegang NPWP dimana beban pajak penghasilan yang dibebankan menjadi dua kali lipat dari pemegang NPWP, yaitu setiap orang yang berkedudukan atau melakukan kegiatan didalam wilayah hukum negara Indonesia melakukan kegiatan handcarry sebagai salah satu bentuk kegiatan untuk mendapatkan keuntungan dari kegiatan handcarry barang impor dimana non pelaku usaha ini menggunakan kegiatan handcarry barang impor sebagai sambilan ketika melakukan perjalanan ke luar negeri, bukan sebagai tujuan utama dari perjalanan ke luar negeri.

Kegiatan jasa titip tidak memiliki batasan khusus atas barang yang ingin di beli oleh pembeli selama barang tersebut merupakan barang yang boleh dibawa selama penerbangan sebagaimana diatur dalam Peraturan Menteri Keuangan Nomor 203/ PMK.04/2017 Tentang Ketentuan Ekspor dan Impor Barang Yang Dibawa Oleh Penumpang dan Awak Sarana Pengangkut. Sedangkan untuk objek dari kegiatan jasa titip impor ialah dari bentuk penghasilan atau upah yang diterima oleh pelaku kegiatan jasa titip melalui penarikan harga barang yang dijatuhkan kepada pembeli lalu dikurangkan oleh pembayaran beban pajak yang melekat pada barang impor dan sisa dari pembayaran-pembayaran yang melekat pada barang impor merupakan penghasilan bersih dari pelaku kegiatan jasa titip barang impor.

\section{B. Prosedur Pemungutan Pajak Penghasilan Kegiatan Jasa Titip Barang Impor}

Pemungutan pajak pengasilan untuk kegiatan jasa titip menggunakan pasal 22 undang-undang sebagai acuan penetapan besaran pajak penghasilan bagi kegiatan jasa titip barang impor karena belum diatur ke dalam peraturan perundang-undangan mengenai kegiatan jasa titip barang impor sehingga penggunaan peraturannya 
mengkuti pertauran yang sudah ada dengan melakukan metode penghalusan hukum. Penghalusan hukum atau dalam bahasa belanda disebut dengan rechtsverfijning yang berasal dari kata fijn yang berarti halus serta dalam bahas inggris disebut dengan refinement of the law yang berarti tindakan penghalusan hukum lazim. Penghalusan hukum dikenal sebagai bagian dari konstruksi hukum yang digunakan sebagai salah satu upaya pengenaan hukum bagi suatu perkara yang belum memiliki peraturan yang mengatur atau digunakan sebagai suatu upaya memenuhi ruang kosong dalam sistem perundang-undangan. Berdasarkan hal tersebut dalam pemungutan pajak penghasilan bagi kegiatan jasa titip dibedakan menjadi dua prosedur yaitu pemungutan pajak penghasilan bagi pelaku kegiatan jasa titip yang memiliki Nomor Pokok Wajib Pajak (NPWP) dan pelaku kegiatan jasa titip yang tidak memiliki Nomor Pokok Wajib Pajak (NPWP), dengan penghitungan pajak penghasilan sebagai berikut :

1. Pelaku kegiatan jasa titip pemegang NPWP

Nomor Pokok Wajib Pajak adalah nomor yang diberikan kepada Wajib Pajak sebagai sarana kepentingan administrasi perpajakan yang digunakan sebagai tanda pengenal diri atau identitas Wajib Pajak dalam melaksanakan hak dan kewajiban perpajakan. ${ }^{4}$ Kepemilikan NPWP bersifat wajib bagi setiap individu yang menjalankan usaha atau pekerjaan bebas, wajib mendaftarkan diri pada Kantor Pelayanan Pajak di wilayah kerja yang menjadi kedudukan Wajib Pajak. ${ }^{5}$ Berdasarkan pasal 22 pajak penghasilan $(\mathrm{PPh})$ penghitungan beban pajak penghasilan bagi pelaku kegiatan jasa titip dengan kepemilikan NPWP adalah sebesar $7.5 \%$ dengan ilustrasi penghitungan pada harga barang impor sebagai berikut:

- Harga barang US\$ 1100

- $\quad$ Pembebasan : US\$ 500

- Harga setelah pembebasan US\$600

- Kurs Dollar Rp. 14.500,00

4 Waluyo, Perpajakan Indonesia (Salemba Empat 2017).[24].

5 ibid. 
- $\quad$ Nilai Pabean : Rp. 8.700.000,00

- $\quad$ Bea Masuk : (10\% x Pabean)

: $10 \% \times 8.700 .000$

: Rp. 870.000,00

- Nilai Impor : (Nilai Pabean + Bea Masuk)

$$
\begin{aligned}
& : 8.700 .000+870.000 \\
& : \text { Rp. } 9.570 .000,00
\end{aligned}
$$

- Pajak Pertambahan Nilai : $10 \%$ dari nilai impor

$$
\text { : } 10 \% \times 9.570 .000
$$$$
\text { : Rp. 957.000,00 }
$$

- Pajak Penghasilan Pasal 22 : 7.5\% dari nilai impor

$$
: 7.5 \% \times 9.570 .000
$$

: Rp. 717.750,00

2. Pelaku kegiatan jasa titip yang tidak memiliki NPWP

Berdasarkan pasal 22 pajak penghasilan $(\mathrm{PPh})$ penghitungan beban pajak penghasilan bagi pelaku kegiatan jasa titip dengan kepemilikan NPWP adalah sebesar 15\% dengan ilustrasi penghitungan pada harga barang impor sebagai berikut:

- Harga barang US\$1500

- Pembebasan : US\$ 500

- Harga setelah pembebasan US\$1000

- Kurs Dollar Rp. 14.500,00

- $\quad$ Nilai Pabean : Rp. 14.500.000,00

- Bea Masuk : (10\% x Pabean)

$$
\begin{aligned}
& : 10 \% \times 14.500 .000 \\
& : \text { Rp. } 1.450 .000,00
\end{aligned}
$$

- Nilai Impor : (Nilai Pabean + Bea Masuk)

$$
\begin{aligned}
& : 14.500 .000+1.450 .000 \\
& : \text { Rp. } 15.950 .000,00
\end{aligned}
$$

- Pajak Pertambahan Nilai : 10\% dari nilai impor 


$$
\begin{aligned}
& : 10 \% \times 15.950 .000 \\
& : \text { Rp. } 1.590 .000,00
\end{aligned}
$$

- Pajak Penghasilan Pasal 22 : 15\% dari nilai impor

$$
\begin{aligned}
& : 15 \% \times 15.950 .000,00 \\
& : \operatorname{Rp} 1.196 .250,00
\end{aligned}
$$

\section{Penegakan Hukum Pengenaan Pajak Penghasilan Bagi Kegiatan Jasa Titip Barang Impor}

A. Tindakan Hukum Pemerintah Terhadap Pelaku Kegiatan Jasa Titip Barang Impor

Tindakan hukum pemerintah dalam kaitannya dengan kegiatan jasa titip barang impor adalah tindakan hukum preventif dan represif. Tindakan preventif dilakukan pemerintah tersebut ialah menetapkan penggunaan peraturan perundang undangan yang relevan bagi kegiatan jasa titip barang impor dikarenakan peraturan perundang-undangan utuh yang mengatur secara spesifik bagi kegiatan jasa titip barang impor belum ada. Peraturan perundang - undangan yang digunakan sebagai bentuk kontrol dari kegiatan usaha jasa titip ialah Peraturan Menteri Keuangan Nomor 203/PMK.04/2017 tentang Ketentuan Ekspor dan Impor Barang yang dibawa oleh Penumpang dan Awak Sarana Pengangkut. Dalam pasal 12 ayat (1) disebutkan pembebanan terhadap barang bawaan dari luar negeri dengan nilai pabean paling banyak FOB USD500.00 (lima ratus United States Dollar), ${ }^{6}$ akan dikenakan:

a. Bea masuk;

b. Pembebanan Pajak Pertambahan Nilai;

c. Pembebanan Pajak Penjualan atas Barang Mewah (jika ada);

d. Pembebanan Pajak Penghasilan.

Pemberian batasan nilai pabean dilakukan karena banyaknya minat perseorangan untuk menjadi perantara jasa jasa titip barang impor sehingga diperlukan sikap unuk melindungi produsen dalam negeri agar tidak kehilangan

\footnotetext{
6 Peraturan Menteri Keuangan Nomor 203/PMK.04/2017 Tentang Ketentuan Ekspor dan Impor Barang yang di Bawa Oleh Penumpang dan Awak Sarana Pengangkut (Berita Negara Republik Indonesia Tahun 2017 Nomor 1900).
} 
daya minat dan gulung tikar dikarenakan kalah bersaing dengan produk luar negeri yang tentunya lebih menarik minat masyarakat. Hal tersebut tentunya menjadi acuan pemerintah untuk mengambil langkah preventif demi melindungi produsen dalam negeri yang terancam karena daya minat beli masyarakat turun karena mudahnya untuk berbelanja dan mendapatkan barang impor melalui jasa jasa titip yang setiap tahun pelaku jasa jasa titip barang impor selalu meningkat dan menarik minat masyarakat untuk memiliki barang impor tanpa harus bepergian ke luar negeri.

Tindakan Represif merupakan suatu tindakan kontrol yang dilakukan pemerintah terhadap pelaku usaha jasa titip barang impor setelah terjadinya pelanggaran norma yang dilakukan oleh pelaku usaha jasa titip barang impor. Terdapat dua bentuk sanksi yang dapat dikenakan yaitu sanksi administrasi dan sanksi pidana yang telah diatur dalam peraturan perundang-undangan bidang perpajakan. Bentuk tindakan represif akan dilakukan ketika pelaku usaha jasa titip melakukan tindakan penyelewengan norma dan atau tidak melakukan pembayaran pembebanan pajak yang telah dibebankan pada mereka dengan tepat waktu dan atau melakukan penghindaran pajak dengan cara memanipulasi barang jasa titip sebagai barang bawaan dari luar negeri sehingga hilang kewajiban atas pajak bagi pelaku usaha jasa titip. Salah satu bentuk kecurangan yang sering dilakukan oleh pelaku usaha jasa titip ini ialah splitting karena batasan nilai barang untuk keluarga tidak masuk dalam pembebanan pajak. Splitting adalah suatu metode yang dilakukan pelaku usaha jasa titip dalam rangka memanipulasi jumlah barang jasa titip agar seharga batas pembebasan bea masuk dan perpajakan senilai USD500 (lima ratus United States Sollar) sehingga tidak terkena beban perpajakan dengan cara membagi atau memecah barang pesanan konsumen kepada pihak keluarga yang ikut serta bepergian luar negeri ataupun kepada pihak lain yang termasuk dalam rombongan pelaku usaha jasa titip tersebut. ${ }^{7}$ Atas tindakan pelaku usaha jasa titip dalam melakukan metode splitting, akan mendapatkan sanksi berupa batas

\footnotetext{
7 Nora Galuh Candra Asmarani, “Bea Cukai Tindak Ratusan Pelanggaran pelaku Jastip” (DDTC NEWS, 2019) <https://news.ddtc.co.id/bea-cukai-tindak-ratusan-pelanggaran-pelaku-jastip-17869>, dikunjungi pada 20 pebruari 2020.
} 
nilai pembebasan tidak berlaku. Selain itu, pelaku usaha jasa titip juga diminta untuk membuat Pemberitahuan Impor Barang Khusus (PIBK) dan membayar kewajiban berupa bea masuk dan pajak dalam rangka impor. ${ }^{8}$ Pelaku usaha jasa titip barang impor yang terbukti melakukan metode splitting agar terhindar dari biaya perpajakan, akan dimintai bukti kepemilikan NPWP. Apabila pelaku usaha jasa titip tidak memiliki Nomor Pokok Wajib Pajak, petugas Bea Cukai akan memintanya untuk membuat NPWP dengan tujuan agar data pelaku usaha jasa titip barang impor dapat ditindaklanjuti oleh Direktorat Jenderal Pajak.

\section{B. Upaya Hukum bagi Pelaku Kegiatan Jasa Titip Barang Impor}

Upaya hukum pada hakikatnya adalah sebuah hak dasar yang dimiliki setiap penduduk yang ditinggal diwilayah suatu negara sebagai bentuk pembelaan diri dan perlindungan diri dari ancaman hukum yang sedang menjeratnya. Upaya hukum dapat dilakukan ketika dugaan penyelewengan aturan hukum tidak sesuai dengan perbuatan yang sebenarnya terjadi. Upaya hukum dapat dilakukan oleh pelaku kegiatan jasa titip apabila diketahui pelaku jasa titip mendapat dugaan perbuatan yang tidak ia lakukan. Bentuk upaya hukum yang dapat dilakukan oleh pelaku kegiatan jasa titip adalah upaya hukum keberatan dan banding.

Keberatan pajak adalah mekanisme yang disediakan Ditjen Pajak bagi Wajib Pajak yang tidak puas dan tidak sependapat terhadap hasil pemeriksaan pajak yang tidak sependapat terhadap hasil pemeriksaan pajak. ${ }^{9}$ Pengajuan keberatan dapat diajukan oleh pelaku kegiatan jasa titip apabila ditemukan adanya jumlah rugi atas pajak, jumlah pajak, dan pemotongan pemungutan pajak tidak sebagaimana mestinya. Keberatan pajak dapat diajukan atas dasar: ${ }^{10}$

a. Surat Ketetapan Pajak Kurang Bayar;

b. Surat Ketetapan Pajak Kurang Bayar Tambahan;

c. Surat Ketetapan Pajak Nihil;

d. Surat Ketetapan Pajak Lebih Bayar;

\footnotetext{
8 ibid.

9 Kezia Rafinska,'Mengenal istilah keberatan pajak" (OnlinePajak, 2018)<https://online-pajak.com/keberatan-pajak>, dikunjungi pada 09 Agustus 2020.

${ }^{10}$ Siti Resmi, Perpajakan teori \& kasus (Salemba Empat 2019).[53].
} 
e. Pemotongan atau pemungutan pajak oleh pihak ketiga berdasarkan peraturan perundang-undangan perpajakan

Pengajuan keberatan pajak memiliki tata cara atau persyaratan yang harus dipenuhi oleh Wajib Pajak agar pengajuan dapat diterima untuk diproses lebih lanjut. Tata cara pengajuan keberatan pajak adalah sebagai berikut: ${ }^{11}$

1. Satu keberatan harus diajukan terhadap satu jenis pajak dan satu masa pajak atau tahun pajak;

2. Keberatan diajukan secara tertulis dalam bahasa Indonesisa dengan mengemukakan jumlah pajak terutang, jumlah pajak yang dipotong, julah rugi menurut penghitungan Wajib Pajak dengan disertai alasan yang menjadi dasar penghitungan;

3. Keberatan harus diajukan dalam jangka waktu tiga bulan sejak tanggal dikirim surat ketetapan pajak atau sejak tanggal pemotongan atau pemungutan pajak, kecuali dalam keadaan force major;

4. Wajib Pajak yang masih mempunyai utang pajak, wajib melunasi pajak paling sedikit sejumlah yang telah disetujui Wajib Pajak dalam pembahasan akhir pemeriksaan, sebelum surat keberatan disampaikan;

5. Keberatan yang tidak memenuhi persyaratan tidak dianggap sebagai surat keberatan sehingga tidak dipertimbangkan.

6. Direktur Jenderal Pajak harus memberikan keputusan atas keberatan yang diajukan dalam jangka waktu 12 (dua belas) bulan sejak tanggal surat keberatan diterima. Apabila Direktur Jenderal Pajak melampaui batas waktu yang telah ditentukan maka putusan keberatan yang diajukan Wajib Pajak dianggap dikabulkan.

7. Terhadap Surat Tagihan Pajak, Surat Ketetapan Pajak Kurang Bayar, serta Surat Ketetapan Pajak Kurang Bayar Tambahan, dan Surat Keputusan Keberatan, Surat Keputusan Pembetulan, Putusan Banding, serta Putusan Peninjauan Kembali, yang menyebabkan jumlah pajak yang harus dibayar bertambah, yang seharusnya dilunasi dalam jangka waktu 1 (satu) bulan sejak tanggal diterbitkan, tetapi belum dibayar pada saat pengajuan keberatan, maka jangka waktu pelunasannya tertangguh ssampai dengan satu bulan sejak tanggal penerbitan Surat Keputusan Keberatan.

8. Terhadap Surat Tagihan Pajak, Surat Ketetapan Pajak Kurang Bayar, serta Surat Ketetapan Pajak Kurang Bayar Tambahan, dan Surat Keputusan Keberatan, Surat Keputusan Pembetulan, Putusan Banding, serta Putusan Peninjauan Kembali, yang dialami oleh Wajib Pajak usaha kecil dan Wajib Pajak didaerah tertentu, yang menyebabkan jumlah pajak yang harus dibayar bertambah, yang seharusnya dilunasi dalam jangka waktu dua bulan sejak tanggal diterbitkan tapi belum dibayar pada saat pengajuan keberatan, maka jangka waktu pelunasannya tertangguh sampai dengan satu bulan sejak tanggal penerbitan Surat Keputusan Keberatan.

11 ibid. [54-55]. 
9. Wajib Pajak yang mengungkapkan pembukuan, catatan, data, informasi, atau keterangan lain dalam proses keberatan yang tidak diberikan pada saat pemeriksaan, selain data dan informasi yang pada saat pemeriksaan belum diperoleh Wajib Pajak dari pihak ketiga, pembukuan, catatan, data, informasi, atau keterangan lain, dimaksud tidak dipertimbangkan dalam penyelesaian keberatannya

Wajib pajak akan menerima Surat Keputusuan Keberatan setelah mengikuti seluruh prosedur pengajuan keberatan. Apabila wajib pajak mendapat putusan ditolak pengajuan keberatannya, wajib pajak dapat mengajukan upaya hukum lain atau lanjutan yaitu banding. Objek banding adalah Surat Keputusan Keberatan, atau kelanjutan dari proses keberatan yang akan diajukan ke Pengadilan Pajak ${ }^{12}$. Pada dasarnya Pengadilan Pajak mengadilu sengketa atas putusan Pejabat Tata Usaha Negara dibidang Perpajakan. Menurut pasal 2 Undang - Undang Nomor 14 Tahun 2002 Tentang Pengadilan Pajak, Pengadilan Pajak adalah badan peradilan yang melaksanakan kekuasaan kehakiman bagi Wajib Pajak atau Penanggung Pajak yang mencari keadilan terhadap sengketa perpajakan ${ }^{13}$. Tata cara pengajuan permohonan banding adalah: ${ }^{14}$

1. Permohonan banding diajukan secara tertulis dalam bahasa Indonesia dengan alasan yang jelas paling lama 3 (tiga) bulan sejak Surat Keputusan Keberatan diterima dan dilampiri dengan Salinan Surat Keputusan Keberatan;

2. Terhadap surat tagihan pajak, Surat Ketetapan Pajak Kurang Bayar, Surat Ketetapan Pajak Kurang Bayar Tambahan, Surat Keputusan Keberatan, Surat Keputusan Pembetulan, Putusan Banding, serta Peninjauan Kembali, yang menyebabkan jumlah pajak yang harus dibayar bertambah, yang seharusnya dilunasi dalam waktu 1 (satu) bulan sejak tanggal diterbitkan tapi belum dibayar pada saat pengajuan keberatan, maka jangka waktu pelunasannya tertangguh sampai dengan 1 (satu) bulan sejak tanggal penerbitan Putusan Banding;

3. Terhadap surat tagihan pajak, Surat Ketetapan Pajak Kurang Bayar, Surat Ketetapan Pajak Kurang Bayar Tambahan, Surat Keputusan Keberatan, Surat Keputusan Pembetulan, Putusan Banding, serta Peninjauan Kembali, yang

\footnotetext{
${ }^{12}$ Ahmad Dimyati, "Pengajuan Keberatan, Banding, dan Peninjauan Kembali Tagihan Bea Masuk" (Pusdiklat Bea dan Cukai, 2014) <https://bppk.kemenkeu.go.id/images/file/pusbc/dmdokumen/2014_Pengajuan_Keberatan_Banding_dan_Peninjauan_Kembali_Tagihan_Bea_Masuk.pdf $>$ dikunjungi 11 agustus 2020 .

${ }^{13}$ Undang - Undang Nomor 14 Tahun 2002 Tentang Pengadilan Pajak (Tambahan Lembaran Negara Republik Indonesia Nomor 4189).

14 Siti Resmi, Op.Cit.[55-56].
} 
dialami oleh Wajib Pajak usaha kecil dan Wajib Pajak di daerah tertentu. Yang menyebabkan jumlah pajak yang harus dibayar bertambah, yang seharusnya dilunasi dalam jangka waktu 2 (dua) bulan sejak tanggal diterbitkannya tapi belum dibayar pada saat pengajuan keberatan, maka jangka waktu pelunasannya tertangguh sampai dengan 1 (satu) bulan sejak tanggal penerbitan Putusan Banding;

4. jumlah pajak yang belum dibayar pada saat pengajuan permohonan banding belum termasuk pajak yang terutang sampai dengan Putusan Banding.

\section{Kesimpulan}

Kegiatan Usaha jasa titip diklasifikan sebagai kegiatan yang ber subjek pajak orang pribadi dan pajak yang dibebankan pada mereka salah satunya adalah pajak penghasilan. Beban Pajak Penghasilan dikenakan dengan dua cara pemungutan yaitu pemungutan pajak bagi Wajib Pajak pelaku usaha jasa titip pemegang Nomor Pokok Wajib Pajak (NPWP) dan Wajib Pajak pelaku usaha jasa titip bukan pemegang Nomor Pokok Wajib Pajak (NPWP). Bagi pemegang NPWP tarif pajak yang dibebankan padanya ialah sebesar $7.5 \%$ dari harga barang yang telah dikenakan biaya bea masuk. Sedangkan untuk Wajib Pajak yang tidak memiliki NPWP dikenakan beban pajak sebesar 15\% dari harga barang yang telah dikenakan biaya bea masuk.

Terhadap proses kegiatan jasa titip barang impor pemerintah memiliki tindakan hukum dalam mengawasi kegiatan jasa titip impor. Tindakan yang dilakukan ialah melalui tindakan preventif dan represif dimana tindakan pengawasan preventif tersebut akan dilakukan pemerintah melalui penerapan peraturan perundang - undangan yang berlaku bagi kegiatan titip impor dikarenakan belum adanya peraturan perundang - undangan yang mengatur lebih spesifik kegiatan titip impor barang impor sehingga diperlukan penggunaan aturan lain yang relevan sebagai bentuk kontrol dan penerapan sanksi ketika ditemukannya penyelewengan oleh pelaku kegiatan jasa titip yang berkaitan dengan pajak penghasilan. 


\section{Daftar Bacaan}

\section{Buku}

Siti Resmi, Perpajakan teori \& kasus (Salemba Empat 2017).

Waluyo, Perpajakan Indonesia (Salemba Empat 2017).

\section{Jurnal}

Ahmad Dimyati , "Pengajuan Keberatan, Banding, dan Peninjauan Kembali Tagihan Bea Masuk" (pusdiklat bea dan cukai 2014) <https://bppk.kemenkeu. go.id/images/file/pusbc/dmdokumen/2014_Pengajuan_Keberatan_Banding_ dan_Peninjauan_Kembali_Tagihan_Bea_Masuk.pdf $>$ dikunjungi 11 agustus 2020 .

\section{Laman}

Kezia Rafinska ,"Mengenal istilah keberatan pajak" (OnlinePajak 2018)<https:// onlinepajak.com/keberatan-pajak>, dikunjungi 09 Agustus 2020.

Nora Galuh Candra Asmarani, "Bea Cukai Tindak Ratusan Pelanggaran pelaku Jastip"(DDTC2019) <https://news.ddtc.co.id/bea-cukai-tindak-ratusanpelanggaran-pelaku-jastip-17869>,dikunjungi 20 pebruari 2020.

Erlin Cahyani Putrim, “Tax Planning Bagi Pelaku Usaha Jasa Titip ditengah Guncangan Kasus Penghindaran Pajak" (Pajakku 2019)<https://www. pajakku.com/read/5d9ff770b01c4b456747b70e/Tax-Planning-BagiPelakuUsaha-Jasa-Titip-di-Tengah-Guncangan-Kasus-Penghindaran-Pajak>, dikunjungi pada tanggal 09 Agustus 2020.

\section{Perundang-undangan}

Undang-Undang Nomor 14 Tahun 2002 Tentang Pengadilan Pajak (Tambahan Lembaran Negara Republik Indonesia Nomor 4189).

Undang-Undang Nomor 36 Tahun 2008 Tentang Pajak Penghasilan (Lembaran Negara Republik Indonesia Tahun 2008 Nomor 133, Tambahan Lembaran Negara Republik Indonesia Nomor 4893).

Peraturan Menteri Keuangan Nomor 203/PMK.04/2017 Tentang Ketentuan Ekspor dan Impor Barang yang di Bawa Oleh Penumpang dan Awak Sarana Pengangkut (Berita Negara Republik Indonesia Tahun 2017 Nomor 1900). 